в закладі освіти (гімназії) на основі диференціації й індивідуалізації під час роботи зі здобувачами освіти.

Компетентнісно-орієнтований підхід до навчального процесу в умовах гімназії орієнтує на розроблення й системне застосування дидактичних тестів із навчального предмета. Гуманітарний профіль передбачає дотримання відповідних характеристик тестів (мовний матеріал класифікується, аналізується 3 позиції формально-граматичних і структурно-семантичних характеристик; мовний матеріал добирається із творів художньої літератури, що сприяє виробленню естетичного смаку учнів, а також сприяє виробленню комунікативностилістичних якостей мовлення). Оскільки в умовах гімназії навчання здійснюється за профілями, дидактичні тести мають специфікацію, передбачають високий творчий рівень здобувачів освіти під час розв'язання таких тестів, відповідно, сприяють формуванню мовної особистості учнів гімназії, інтенсифікують розвиток фахового мислення майбутніх спеціалістів, Активізація освітньої, розвивальної й мотиваційної функцій контрольних тестів як компонента контрольнооцінювальної діяльності в гімназії відбувається з урахуванням моделювання освітньої траєкторії здобувачів освіти, що передбачає гнучке застосування дидактичних тестів з урахуванням складності завдань / iз розподілом завдань за рівнем засвоєння навчального матеріалу.

\title{
Література:
}

1. Булах I. Є., Мруга М. Р. Створюємо якісний тест : навчальний посібник. Київ : Майстер-клас, 2006. 160 с.

DOI https://doi.org/10.30525/978-9934-26-114-5-24

\section{ЗМІСТ ТОЛЕРАНТНОСТІ ОСОБИСТОСТІ ВІЙСЬКОВОСЛУЖБОВЦЯ НАЦІОНАЛЬНОЇ ГВАРДІЇ УКАЇНИ}

\author{
Тробюк Н. Ю. \\ викладач кафедри психології та педагогіки \\ Наџіональна академія Начіональної гвардї України \\ м. Харків, Україна
}

Декларація принципів толерантності [1] наголошує про особливу важливість толерантності в сучасному світі, про ії глобальний характер, необхідність формування атмосфери толерантності у взаєминах, 
необхідність здійснювати відповідні наукові дослідження забезпечення рівності у праві на гідність та інших правах окремих осіб і груп людей.

Національна гвардія України (НГУ) є військовим формуванням 3 правоохоронними функціями, що входить до системи Міністерства внутрішніх справ України і призначена для виконання завдань із захисту та охорони життя, прав, свобод і законних інтересів громадян, суспільства і держави від злочинних та інших протиправних посягань, охорони громадського порядку та забезпечення громадської безпеки [2]. Оскільки НГУ є одним із тих державних органів за допомогою якого в суспільстві відбувається протидія негативним впливам, а також формуванням, що здатне особистим прикладом під час виконання професійних обов'язків сприяти вірному i відкритому діалогу та спілкуванню, виникає необхідність дослідження змісту толерантності у військовому середовищі.

Наша мета дослідити зміст толерантності для можливості зрозуміти й урахувати якісні характеристики толерантності у процесі професійної підготовки майбутнього офіцера.

У науковій літературі, поняття «толерантність», має широкий спектр та тлумачення. Вивчення досліджень Л. Бернадської; С. Братченка; М. Пірена; А. Молчанової, О. Брюховецької; Г. Солдатотової; О. Гриви та інш., що стосуються проблеми виховання толерантності у різних наукових напрямах: філософських, психологічних, соціологічних та педагогічних, дозволило нам констатувати неоднозначність поглядів на поняття «толерантність».

Враховуючи, що підготовка військовослужбовців має свою специфіку, нас зацікавили дослідження науковців: В. Аніщенко, С. Денисенко, Л. Гребенюк, В. Желязкова, О. Марченко, К. Тушко, що розглядали різні аспекти професійної підготовки цих фахівців. У результаті аналізу було встановлено, що толерантність виступає однією із умов професійної підготовки фахівців військової сфери.

Для більш об'єктивного визначення змісту поняття толерантності офіцера НГУ, нами проведено опитування військовослужбовців НГУ за допомогою авторської анкети «Стан сформованості толерантності офіцера НГУ». Опитуванням було охоплено 120 осіб з них: 60 (50 - чоловіків, 10 - жінок) військовослужбовців НГУ, що навчаються у Національній академії НГУ за освітньо-кваліфікаційним рівнем вищої освіти «магістр», оперативного рівня військової освіти та 60 (20 - жінок, 40 - чоловіків) військовослужбовців НГУ - за освітньо-кваліфікаційним рівнем «бакалавр», тактичного рівня військової освіти. Для визначення ступеню важливості якостей, що притаманні толерантній особистості, опитуваним було запропоновано ряд якостей, які пропонувалося оцінити 
за п'яти бальною шкалою. За усередненою ознакою ми отримали певні значення досліджуваної ознаки (варіанту), а для кращого сприймання відобразили результати у таблиці. (табл.1).

Таблиця 1

\begin{tabular}{|c|c|c|c|c|c|}
\hline $\begin{array}{c}\text { №3/ } \\
\text { П }\end{array}$ & Назва якості & $\begin{array}{c}\text { в/сл } \\
\text { оперативн } \\
\text { ого рівня }\end{array}$ & $\begin{array}{c}\text { в/сл } \\
\text { тактичног } \\
\text { о рівня }\end{array}$ & в/сл жінки & $\begin{array}{c}\text { в/сл } \\
\text { чоловіки }\end{array}$ \\
\hline 1 & $\begin{array}{c}\text { Уміння уважно } \\
\text { слухати і чути не } \\
\text { перебиваючи і не } \\
\text { відволікаючись }\end{array}$ & 3,5 & 4,4 & 4,4 & 3,7 \\
\hline 2 & $\begin{array}{c}\text { Шанобливе } \\
\text { звернення один до } \\
\text { одного, без різких } \\
\text { викриків, обзивань і } \\
\text { кличок }\end{array}$ & 3,8 & 4,3 & 4,7 & 3,8 \\
\hline 3 & $\begin{array}{c}\text { Прагнення } \\
\text { розібратися в } \\
\text { проблемі чи темі, не } \\
\text { ігноруючи } \\
\text { незрозумілі місця, } \\
\text { розпитування, } \\
\text { уточнення, } \\
\text { демонстрування } \\
\text { зацікавленості }\end{array}$ & 3,3 & 4,1 & 4,5 & 3,4 \\
\hline 4 & $\begin{array}{c}\text { Готовність прийняти } \\
\text { і дати пораду }\end{array}$ & 3,8 & 4,2 & 4,2 & 3,8 \\
\hline 5 & $\begin{array}{c}\text { Уміння хвалити, } \\
\text { погоджуватись, } \\
\text { розраджувати }\end{array}$ & 3,2 & 3,5 & 3,3 & 3,4 \\
\hline 6 & Доброзичливість & 3,7 & 4,1 & 4,2 & 3,7 \\
\hline 7 & $\begin{array}{c}\text { Повага особистості, } \\
\text { спілкування без } \\
\text { приниження, погроз, } \\
\text { без осудження і } \\
\text { критики }\end{array}$ & 4,2 & 4,5 & 4,8 & 4,2 \\
\hline
\end{tabular}




\begin{tabular}{|c|c|c|c|c|c|}
\hline \multicolumn{6}{|c|}{ Продовження таблиці 1} \\
\hline 8 & $\begin{array}{c}\text { Уміння } \\
\text { співпереживати, } \\
\text { не звинувачуючи і } \\
\text { без дорікань }\end{array}$ & 3,4 & 3,9 & 4,7 & 3,3 \\
\hline 9 & $\begin{array}{c}\text { Прагнення } \\
\text { підтримати один } \\
\text { одного, } \\
\text { підбадьорити }\end{array}$ & 3,7 & 4 & 4,1 & 3,7 \\
\hline 10 & $\begin{array}{c}\text { Визнання права } \\
\text { кожного бути } \\
\text { самим собою }\end{array}$ & 3,2 & 4,6 & 4,2 & 3,6 \\
\hline
\end{tabular}

Розглядаючи результати опитування за категоріями, нами встановлено, що жінки-військовослужбовці майже всім якостям надають більшого значення ніж чоловіки-військовослужбовці, а також значення результатів військовослужбовців тактичного рівня військової освіти вищі ніж результати військовослужбовців оперативного рівня військової освіти. Найбільшого значення при опитувані всіх категорій визначили серед якостей, що притаманна, на їхню думку, толерантній особистості - повагу особистості, спілкування без приниження, погроз, без осуду i критики. На нашу думку, вона тісно пов'язана 3 толерантністю і додає їй позитивну моральну якість, яка спочатку вимагає розуміння, а потім можливість морального судження. Найменшого значення надали - умінню хвалити, погоджуватись, розраджувати. Можна припустити, що оскільки опитувані - це люди військові і звикли діяти відповідно до нормативних актів, які передбачають схвалення як один 3 видів заохочення [3], більшість опитуваних не надали такого важливого значення цій якості по відношенню до толерантності особистості. Проте серед явищ, що мають місце частого прояву у військовому колективі було відмічено і егоцентризм - 8\%; і ігнорування іншої людини - 10\%. Оскільки ефективність діяльності військовослужбовців залежить від того, чи здатна людина сприймати іншу людину в якості рівноправного партнера, а для цього, необхідно навчитися долати власний егоцентризм, переключати увагу з власних дій і переживань на партнера (його дії та переживання), на нашу думку, саме формування толерантності допоможе у цьому процесі. Інші якості мають приблизно однакові 
показники. Це вказує, що всі вони можуть наповнювати зміст толерантності офіцера НГУ, оскільки є важливими для них в якості толерантної особистості.

Дуже важливим для нашого дослідження було встановити які надії покладають на толерантність військовослужбовці, як опитуванні вважають, чого можна досягти завдяки толерантності. На їхню думку за допомогою толерантності можна досягти : миру - $14 \%$; поваги $17 \%$; успіху $-15,5 \%$; авторитету -17 ; психологічної стійкості $-15,6 \%$ уникнути конфліктів у взаємовідносинах - 16\%. Також, дехто із опитуваних вважає, що толерантність заважає - $3 \%$, обгрунтовуючи свою думку специфікою служби.

Отже, враховуючи зазначене, майбутній офіцер НГУ повинен володіти такою якістю як толерантність, що проявлятиметься в повазі до інших, та відображатиметься сукупністю умінь та навичок у здатності проявляти терпимість до різних поглядів, норм поведінки, звичок особи, групи осіб, з якими офіцер здійснює комунікації у процесі службово-бойової діяльності, керуючись вимогами нормативно-правових актів.

\section{Література:}

1. Декларація принципів толерантності ЮНЕСКО : Міжнародний документ від 16.11.1995. / База даних «Законодавство України». URL : http://zakon2.rada. gov.ua/laws/show/995_503 (дата звернення 16.06.2021)

2. Про Національну гвардію України: Закон України від 13.03.2014 №876-VII.// База даних «Законодавство України» / ВР України. URL : https://zakon.rada.gov.ua/laws/show/876-18 (дата звернення: 15.06.2021)

3. Закон України Про Дисциплінарний статут Збройних Сил України https://zakon.rada.gov.ua/laws/show/551-14\#Text (дата звернення: 15.06.2021)

4. Тушко О. Г. Система підготовки майбутніх офіцерів державної прикордонної служби України до професійної взаємодії : дис. ... д-ра. пед. нук : 13.00.04. Хмельницький, 2020. 529 с.

5. Пірен М. І. Толерантність - дієвий чинник злагоди та консолідації в сучасному українському суспільстві. Вісник Національної академії державного управління при Президентові Украӥни. 2015. № 2. С. 51-56.

6. Тробюк Н. Ю., Коломієць М. Б. Толерантність як професійно важлива якість майбутніх офіцерів Національної гвардії України. Педагогіка формування творчої особистості у вищій $i$ загальноосвітній школах. Запоріжжя : КПУ, 2020. № 70. С. 161-166 